\title{
Pulse drip irrigation and fertigation water depths in the water relations of coriander
}

\author{
Valentin Ruben $O$ Zamora ${ }^{1} \mathbb{D}$; Manasses $M$ da Silva ${ }^{1} \mathbb{D}$; Geronimo F da Silva ${ }^{1} \mathbb{D}$; José Amilton Santos \\ Júnior ${ }^{1} \mathbb{D}$; Dimas Menezes ${ }^{1} \mathbb{D}$; Sirleide Maria de Menezes ${ }^{1} \mathbb{D}$
}

${ }^{1}$ Universidade Federal Rural de Pernambuco (UFRPE), Recife-PE, Brazil; vorcon2871@gmail.com; manasses.ufrpe@gmail.com; geronimo. silva@ufrpe.br; joseamilton.santosjunior@ufrpe.br; dimasmenezes@superig.com.br; sirleidemeneses@hotmail.com

\begin{abstract}
This study was installed to evaluate the effect of pulse drip irrigation under different water depth levels (fertigation) in the main water relations of coriander crop (Coriandrum sativum). The experiment was installed under protected environment conditions, at UFRPE, Recife, Brazil. The experimental design was randomized blocks in a $2 \times 5$ factorial scheme, with three replications. Treatments consisted of two application types (continuous and pulsed irrigation), and five water depths with replacement of $40,60,80,100$ and $120 \%$ of crop evapotranspiration (ETc). Water demand was estimated through water balance using a drainage lysimetry. Six irrigation pulses were defined with a 60 -minute-rest interval between two successive applications. Plants irrigated by pulses showed higher water productivity values (fresh and dry mass), higher water content (shoot and root), higher shoot mass production index and lower root mass production index and root-shoot ratio. The reduction of applied fertigation water depths increased plant water stress index. The irrigation pulses used ensured water content able to maintain the crop's marketable quality. Pulse application in irrigation system increased shoot mass production index and reduced root mass production index.
\end{abstract}

Keywords: Coriandrum sativum, intermittent irrigation, water deficit, dripping irrigation system.

\section{RESUMO}

Gotejamento por pulsos e lâminas de fertirrigação nas relações hídricas do coentro

O presente trabalho foi desenvolvido com o objetivo de avaliar o efeito do gotejamento por pulsos, sob diferentes níveis da lâmina de fertirrigação, nas principais relações hídricas da cultura do coentro (Coriandrum sativum). O experimento foi realizado em condições de ambiente protegido, nas dependências da UFRPE, campus Dois Irmãos, Recife-PE. O delineamento experimental foi de blocos casualizados em esquema fatorial $2 \times 5$, com três repetições. Os tratamentos consistiram de dois tipos de aplicação (irrigação contínua e por pulsos) e cinco lâminas de reposição da fertirrigação de 40, 60, 80,100 e $120 \%$ da evapotranspiração de cultivo (ETc). A demanda de água foi estimada por balanço hídrico via lisimetria de drenagem. Foram definidos seis pulsos de irrigação com intervalo de 60 minutos de repouso entre duas aplicações sucessivas. As plantas irrigadas por pulsos apresentaram maior produtividade de água (massa seca e fresca), maior teor de água (parte aérea e raíz), maior índice de produção de massa na parte aérea e menor índice de produção de massa na raiz e razão raiz parte aérea. A redução das lâminas de fertirrigação aplicadas aumentou o índice de estresse hídrico das plantas. Os pulsos de irrigação utilizados garantiram um teor de água na planta capaz de manter a qualidade comerciável da cultura. A aplicação dos pulsos na irrigação aumentou o índice de produção de massa da parte aérea e reduziu o índice de produção de massa da raiz.

Palavras-chave: Coriandrum sativum, irrigação intermitente, déficit hídrico, irrigação localizada.

\section{Received on April 9, 2018; accepted on November 20, 2018}

$I^{2}$ Brazil, rainfall scarcity and irregularity are among the main limiting factors for agricultural production. In the Northeastern part of the country, even under unfavorable water availability conditions, agriculture has prominent role in the regional economy. In Sertão Region prevails subsistence farming and this agriculture practice is sometimes hampered by droughts (Castro, 2013). Thus, using more efficient irrigation systems is essential for the sector sustainability (Lima et al., 2011).

Among important crops, in the Northern and Northeastern regions of the country, the coriander stands out. Coriander is an annual herbaceous vegetable that, due to its versality, is of considerable value and great socioeconomic importance. The crop is cultivated mostly by small and mediumsized farmers, in order to be used as spice. This herb is commercialized in outdoor markets and supermarkets and the fruits are used for industries (Maciel et al., 2012).

Due to weather conditions of the region, coriander is grown using irrigation. Generally, it is exploited in small areas with water from small sources such as ponds, Amazon wells, natural wells in riverbeds, tubular wells, among others (Medeiros et al., 1998). During its cultivation, irrigation systems and high frequency fertigation can be 
adopted in order to save water, control external solute movement and improve product quality.

On the other hand, the authors highlight that the used water has to be totally available for the crop, through an efficient application and soil storage. A technique to maximize the use of water is pulse irrigation, which consists of a more frequent, split water application. Thus, using this technique, it is expected to save water, which would be eventually wasted in a continuous irrigation, due to evaporation or deep percolation losses (Nascimento et al., 2013).

Moreover, water splitting allows to keep water and soluble nutrients near the active root zone of the crop, resulting in a reduced risk of water and nutrients to move under the root zone.

To ensure good productivity, irrigation can be associated with nutrients, essential to the crop, using fertigation. In order to make this practice efficient, a balance between quantity of nutrients and applied water is necessary, to maintain appropriate concentration of fertilizers in the irrigation water, for an appropriate crop development, providing nutrient absorption in required quantities.

Water and nutrient use is related to water use efficiency, which is expected to be increased under fractional management, as evidenced by Almeida et al. (2015), for replacement of 75\% ETc. Warner et al. (2009), evaluating tomato crop, verified water savings of $40 \%$, keeping productivity and quality of crop. Abdelraouf et al. (2012), studying potato, noticed an increase of $63.90 \%$ in water productivity, applying pulse treatments, highlighting water savings of up to $25 \%$ per crop cycle.

Given the above, considering scarcity of information, this study aimed to evaluate the effect of pulse drip irrigation under different levels of fertigation, considering main water variables and water use efficiency by the coriander crop.

\section{MATERIAL AND METHODS}

The experiment was carried out between August and September, 2017, in
Agronomy Department of Universidade Federal Rural de Pernambuco, Campus Dois Irmãos, Recife PE, Brazil ( $8^{\circ} 1^{\prime} 7^{\prime}$ ' S; 3456'46”'W; 6,5 m altitude).

According to Köppen's classification, the local climate is classified As', hot and humid tropical, rainfall during autumn and winter, presenting a dry season, which extends from September to February, and a rainy season from March to August (Jales et al., 2012). Temperature and relative humidity were monitored via ARDUINO; average maximum temperature of $34.35^{\circ} \mathrm{C}$ and average minimum temperature of $25.66^{\circ} \mathrm{C}$; the average maximum relative humidity observed was $92.22 \%$ and average minimum relative humidity was $55.90 \%$.

Experimental units were installed in a protected environment measuring 162 $\mathrm{m}^{2}$, greenhouse, chapel type, consisting of 30 masonry seedbeds, $1.0 \mathrm{~m}^{2}(5.0 \mathrm{x} 0.2$ $\mathrm{m})$ and $0.2 \mathrm{~m}$ deep. Each seedbed was waterproofed with plastic polyethylene film and equipped with a drainage system.

The soil used in this study presented sandy texture, $904 \mathrm{~g} \mathrm{~kg}^{-1}$ of sand, $32 \mathrm{~g}$ $\mathrm{kg}^{-1}$ of silt and $64 \mathrm{~g} \mathrm{~kg}^{-1}$ of clay. Soil densities and particles were 1.5 and 2.5 $\mathrm{kg} \mathrm{dm}{ }^{-3}$, respectively. Water contents equivalent to the field capacity were 0.10 $\mathrm{m}^{3} \mathrm{~m}^{-3}$ and permanent wilting point was $0.09 \mathrm{~m}^{3} \mathrm{~m}^{-3}$. Chemical soil properties, before the experiment installment were: $\mathrm{pH}($ water $1: 2.5)=5.1 ; \mathrm{Ca}^{2+}=2.0 \mathrm{cmol}_{\mathrm{c}}$ $\mathrm{dm}^{-3} ; \mathrm{Mg}=1.5 \mathrm{cmol}_{\mathrm{c}} \mathrm{dm}^{-3} ; \mathrm{Al}=0.2 \mathrm{cmol}_{\mathrm{c}}{ }^{\mathrm{c}}$ $\mathrm{dm}^{-3} ; \mathrm{Na}=0.01 \mathrm{cmol}_{\mathrm{c}} \mathrm{dm}^{-3} ; \mathrm{K}=0.01$ $\mathrm{cmol}_{\mathrm{c}} \mathrm{dm}^{-3} ; \mathrm{P}=2.0 \mathrm{mg} \mathrm{dm}^{-3} ; \mathrm{M} . \mathrm{O} .=9.69$ $\mathrm{g} \mathrm{kg}^{-1} ; \mathrm{H}+\mathrm{Al}=4.68 \mathrm{cmol}_{\mathrm{c}} \mathrm{dm}^{-3}$.

Randomized block design, in a factorial scheme $2 \times 5$, was used. Treatments consisted of two water application types (pulse and continuous irrigation) and five fertigation water depths with replacement of 40,60, 80, 100 and $120 \%$ crop evapotranspiration (ETc), with three replications, totalizing ten treatments, making 30 experimental plots. Six irrigation pulses with a 60-minute break between two successive irrigations were defined. ETc was determined by water balance using a drainage lysimetry installed in 5.0-liter pots inside the greenhouse. ETc was calculated using the average of four observations.

Plots were irrigate using a drip tape (DN $16 \mathrm{~mm}$ ); spacing among drippers was $0.30 \mathrm{~m}$, nominal flow was $0.60 \mathrm{~L} \mathrm{~h}^{-1}$ and operating pressure of $10 \mathrm{mca}$. For an appropriate operation, drain valves, solenoid valves, pressure regulator, filter, microcontroller and a pumping system with installed capacity of 0.5 CV were used.

Irrigation time was determined considering the irrigation water depth to be applied in each treatment. Irrigation water depth was obtained using simple relationship between ETc and average efficiency of the irrigation system (90\%).

Differences between treatments were observed from $10^{\text {th }}$ day after sowing. Until this day, all plots were irrigated daily, applying $100 \%$ of ETc continuously, totalizing $19.2 \mathrm{~mm}$.

Water depth split application and calculus of application times were done automatically, according to each treatment, through an electronic control circuit ARDUINO. Daily irrigations were done always at 9 a.m.

\section{Description and conduction of the crop}

Coriander cultivar Verdão was sown directly in the experimental units, placing 20 seeds per pit, spacing $10 \times 15 \mathrm{~cm}$. Plants were thinned ten days after sowing, leaving six plants per pit. Sampling useful area at harvest was 1.0 $\mathrm{m}^{2}$ per plot.

Agricultural limestone (calcitic) was applied (484 $\left.\mathrm{kg} \mathrm{ha}^{-1}\right)$ in order to correct soil acidity and neutralize exchangeable Al. Liming and phosphate fertilization (127 $\mathrm{kg} \mathrm{ha}^{-1}$ simple superphosphate) was performed conventionally, done according to the methodological procedures recommended by Cavalcanti et al. (2008). The macro and micronutrients, essential to the crop, were applied daily via fertigation, according to Furlani (1998).

\section{Water consumption}

During the experiment, 34 daily irrigations were applied. Irrigation water depth was established considering a range of $20 \%$, from the lowest water depth $40 \%$, up to $120 \%$ replacement ETc, totalizing $54.4 \mathrm{~mm}$ and $124.8 \mathrm{~mm}$, 
respectively. Differentiated water depths for each treatment are shown in Table 1.

Two evaluations were performed in order to verify water distribution uniformity in the irrigation system, one at the beginning and another at the end of the experiment, according to the methodology described by Merriam \& Keller (1978). For an average operating pressure of 10.0 mca the average flow of the drippers was $0.55 \mathrm{~L} \mathrm{~h}^{-1}$. The coefficient of water distribution uniformity for the beginning and the end of the experiment was 98.20 and $97.09 \%$, respectively.

\section{Evaluated variables}

\section{Water stress index}

Crop water stress index was calculated using the difference of the leaf temperature and the temperature inside the greenhouse, following the methodology of Idso et al. (1977), according to equation 1.

$\mathrm{WSI}=\mathrm{T}_{\mathrm{L}}-\mathrm{T}_{\mathrm{A}}$

In which $\mathrm{WSI}=$ water stress index $\left({ }^{\circ} \mathrm{C}\right) ; \mathrm{T}_{\mathrm{L}}=$ leaf temperature $\left({ }^{\circ} \mathrm{C}\right) ; \mathrm{T}_{\mathrm{A}}=$ air temperature $\left({ }^{\circ} \mathrm{C}\right)$.

Leaf temperature was registered daily using a portable digital infrared thermometer, at the time of maximum solar radiation of the day. Air temperature was measured using a calibrated electronic temperature and humidity sensor, installed in the experimental area.

\section{Water productivity}

Water productivity was determined as an indicator of the efficiency of agricultural water use to increase the crop yield. Water productivity was obtained through the ratio of total crop production (fresh and dry) and volume of applied water, according to equations 2 and 3.

$$
\begin{array}{r}
\text { WPFM }=\frac{T F M}{T D M} \\
W P D M=\frac{T D M}{T W C}
\end{array}
$$

In which WPFM= water productivity in fresh mass production $\left(\mathrm{g} \mathrm{L}^{-1}\right)$; $\mathrm{WPDM}=$ water productivity in dry mass production $\left(\mathrm{g} \mathrm{L}^{-1}\right)$; TFM= total fresh mass $(\mathrm{g})$; TDM= total dry mass (g); TWC $=$ total water consumption $(\mathrm{L}$ plant $\left.^{-1}\right)$.

\section{Root and shoot water content}

Root and shoot water content was calculated using the ratio between fresh and dry mass of shoot and root, according to the methodology proposed by Benincasa (1988), following the equations 4 and 5.

$$
\begin{aligned}
& \mathrm{SWC}=\left(\frac{\mathrm{SFM}-\mathrm{SDM}}{\mathrm{SDM}}\right) 100 \\
& \mathrm{RWC}=\left(\frac{\mathrm{RFM}-\mathrm{RDM}}{\mathrm{RDM}}\right) 100
\end{aligned}
$$

In which $\mathrm{SWC}=$ shoot water content (\%); $\mathrm{SFM}=$ shoot fresh mass (g); $\mathrm{SDM}=$ shoot dry mass $(\mathrm{g})$; RWC $=$ root water content (\%); RFM= root fresh mass (g); $\mathrm{RDM}=$ root dry mass (g).

\section{Shoot and root mass production index}

Shoot and root mass production index was calculated using the ratio between shoot and root dry mass and total dry mass, according to Benincasa (1988), using equations 6 and 7.

$$
\begin{aligned}
& \mathrm{SMPI}=\frac{\mathrm{SDM}}{\mathrm{TDM}} \\
& \mathrm{RMPI}=\frac{\mathrm{RDM}}{\mathrm{TDM}}
\end{aligned}
$$

In which $\mathrm{SMPI}=$ shoot mass production index; RMPI = root mass production index; SDM= shoot dry mass (g); RDM= root dry mass (g); TDM= total dry mass $(\mathrm{g})$.

\section{Root-shoot ratio}

The root-shoot ratio is the index which allows to evaluate the effect of water stress and salinity conditions in soil, through evaluating the highest and the lowest development of roots in relation to shoot part of the plant, in order to improve water absorption process and soil nutrients.

The root-shoot ratio ( $\mathrm{RSr}$ ) was calculated relating the root dry mass and shoot dry mass, according to Magalhães (1979), using equation 8.

$$
\mathrm{RSr}=\left(\frac{\mathrm{RDM}}{\mathrm{SDM}}\right) 100
$$

In which $\mathrm{RSr}=$ root-shoot ratio (dimensionless); RDM= root dry mass (g); DM= shoot dry mass (g).

\section{Statistical analysis}

Obtained results were submitted to the variance analysis using $\mathrm{F}$ test. When some significant effect was verified, the authors performed the regression analysis for the quantitative factor and agglomerative Scott Knott test at 5\% significance for qualitative factor, using computer statistical software SISVAR (Ferreira, 2011).

\section{RESULTS AND DISCUSSION}

Variance analysis showed a significant effect $(\mathrm{p}<0.01)$ concerning the type of application and fertigation water depth in relation to root water content (RWC), shoot and root mass production index (SMPI, RMPI) and root-shoot ratio ( $\mathrm{RSr}$ ). The authors noticed significant effect $(\mathrm{p}<0.01)$ only for fertigation water depth in relation to water stress index (WSI) and shoot water content (SWC). For water productivity of fresh and dry mass production (WPFM, WPDM), an interaction between the two factors was noticed $(\mathrm{p}<0.01)$.

Water stress index (WSI) of coriander linearly decreased in the ratio $0.058^{\circ} \mathrm{C}$ for each $1 \%$ increase in replacement water depth independently of the type of application (Figure 1A). The fact that WSI increases in relation to the reduction of water depth, makes it clear that plants submitted to water deficit transpired less due to the stomatal closing in the leaves, resulting directly in higher values of leaf temperature.

For all treatments, negative values of WSI were observed, showing that plants which did not suffer from water stress, maintained leaf surface temperature below air temperature. This fact was probably because of the greenhouse cover, which decreased the effect of the sun's rays, besides the adaptation of the genotype used to the climatic conditions of the northeast region.

Shoot water content (SWC) of the coriander adjusted to a quadratic model (Figure 1B). SWC decreased in relation to the reduction of water depth because of a negative effect of the plant biological processes, resulting in a decrease of fresh mass accumulation. According to Eid et al. (2013), this fact is explained due to an increase of soil surface evaporation rate caused by intervals between pulses. These intervals provide an increase in salt concentration near plant root area. Thus, because of an increase in osmotic potential and, therefore. probability 
of plasmolysis (loss of water through osmosis), a decrease in fresh matter is noticed.

For fresh mass water productivity, the authors observed adjustment to quadratic model to the averages of obtained data, WPFM of pulse-irrigated plants was higher $(\mathrm{p}>0.01)$ an average of $43.04 \%$ in comparison to continuouslyirrigated plants (Figure 2A), with a possibility of reaching maximum WPFM of $20.40 \mathrm{~g} \mathrm{~L}^{-1}$ for a water depth of $71.60 \%$ ETc. Plants irrigated continuously reached a WPFM of 12.97 $\mathrm{g} \mathrm{L}^{-1}$, replacing $100 \%$ of ETc (Figure 2 ). This fact highlights the superiority of productivity of water on fresh matter of coriander when pulse irrigation technique is used.

For water productivity on dry mass

Table 1. Fertigation water depths applied in each treatment. Recife, UFRPE, 2017.

\begin{tabular}{lccc}
\hline $\begin{array}{l}\text { Fertigation water } \\
\text { depths (\%ETc) }\end{array}$ & Type of application & $\begin{array}{c}\text { Water depth } \\
(\mathbf{m m})\end{array}$ & $\begin{array}{c}\text { Total water } \\
\text { depth }(\mathbf{m m})\end{array}$ \\
\hline 120 & Pulses or continuous & 105.6 & 124.8 \\
100 & Pulses or continuous & 88.0 & 107.2 \\
80 & Pulses or continuous & 70.4 & 89.6 \\
60 & Pulses or continuous & 52.8 & 72.0 \\
40 & Pulses or continuous & 35.2 & 54.4 \\
\hline
\end{tabular}

(Figure 2B), the authors verified that productivity of pulse-irrigated plants was superior $(\mathrm{p}>0.01)$ in relation to productivity of continuously-irrigated plants. The average increase observed was $41.12 \%$. Under pulse irrigation, a maximum WPDM of $2.21 \mathrm{~g} \mathrm{~L}^{-1}$ for a water depth of $68.88 \%$ ETc can be reached, being this productivity superior than the one obtained by continuous irrigation replacing 100\% ETc. As verified for fresh mass water productivity, pulse irrigation provided higher water productivity $(p>0.01)$ in dry matter (WPDM) of the coriander, except for water depths of 120 and $100 \%$ ETc. This finding demonstrates the benefit of pulse irrigation use in WPDM of coriander. One plausible explanation for the benefit of this technique on water productivity in fresh and dry matter is that the water application

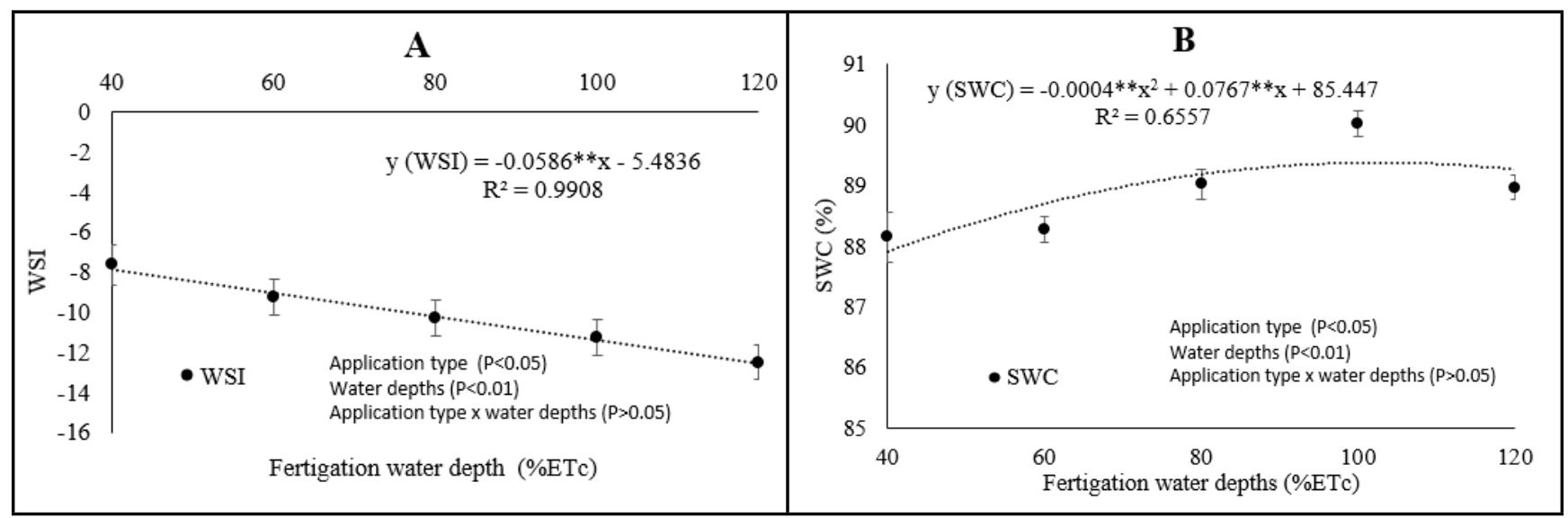

Figure 1. Effect of fertigation water depths on water stress index (WSI) and shoot water content (SWC) on coriander cv. Verdão cultivated under protected environment conditions. Bars represent standard error of averages. Recife, UFRPE, 2017.
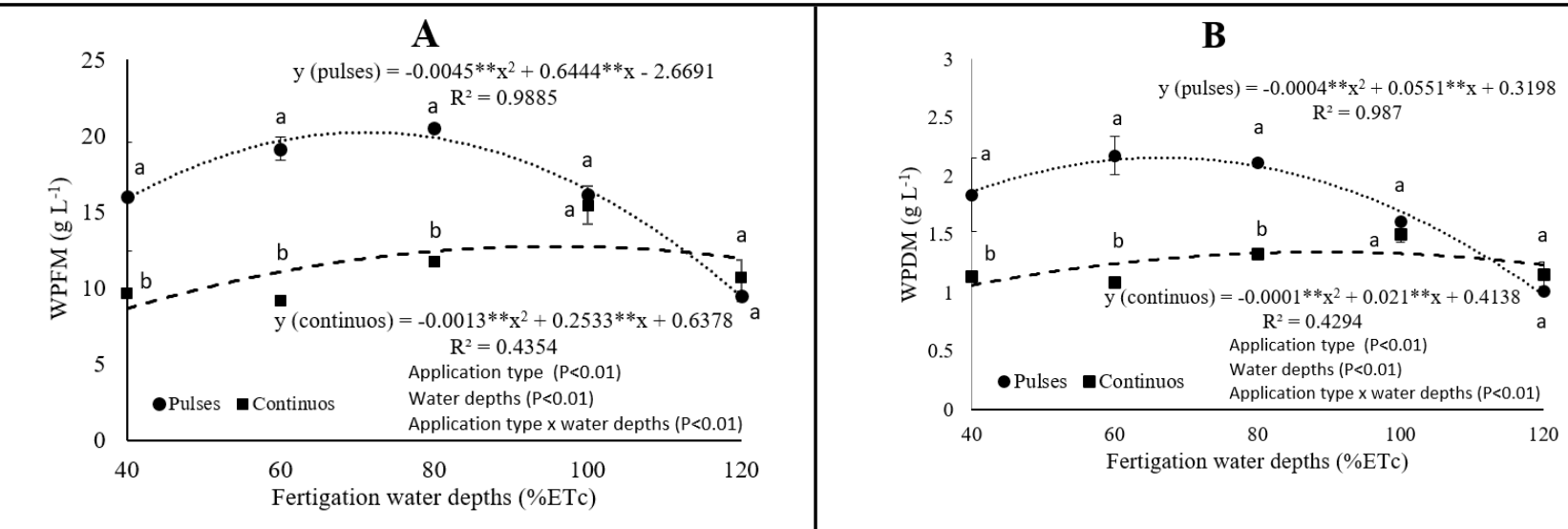

Figure 2. Analysis of interaction between type of application and fertigation water depths for water productivity in fresh and dry mass production (WPFM, WPDM) of cv. Verdão cultivated under protected environment conditions. Bars represent the standard error of averages; different letters indicate significant differences between treatments by Scott Knott test, P<0.05. Recife, UFRPE, 2017. 


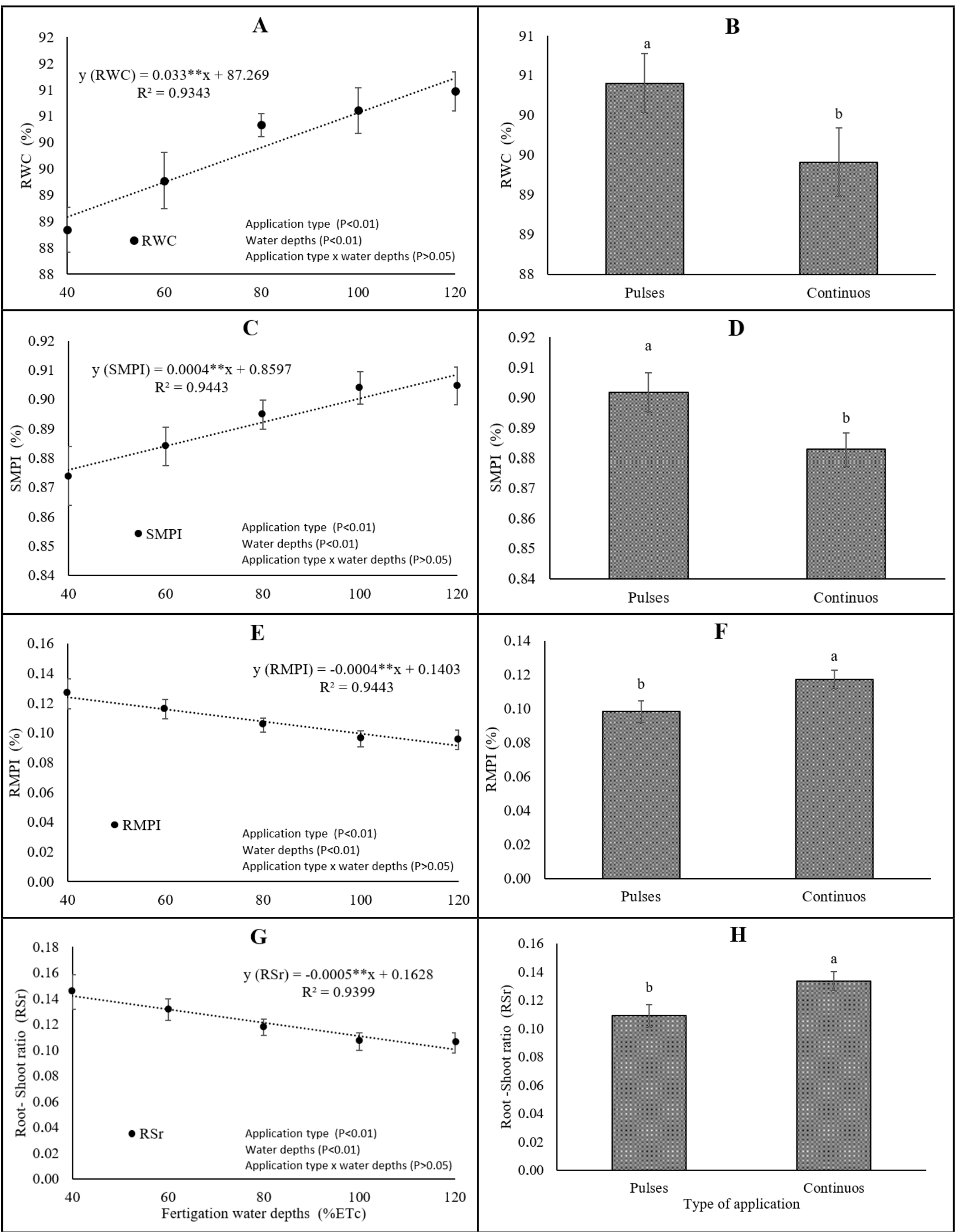

Figure 3. Analysis of type of application effect and fertigation water depths in root water content (RWC) (A and B), shoot mass production index (SMPI) (C and D), on root mass production index (RMPI) (E and F) and root-shoot ratio (RSr) (G and H), on coriander cv. Verdão cultivated under protected environment conditions. Bars represent standard error of averages. Different letters indicate significant differences between treatments by Scott Knott test, P<0.05. Recife, UFRPE, 2017. 
occurs at practically the same rate as the evapotranspiration of the crop occurs during the day (Abdelraouf et al., 2012).

Root water content (RWC) increased linearly in relation to applied water depths, considering an increase of $0.033 \%$ for each $1 \%$ increase of applied water depth, independently of the type of application (Figure 3A). This increase is due to the fact that treatments with higher water depths concentrate higher water content and, therefore, higher fresh matter than the treatments in which less water is provided. According to Figure 3B, the authors observed that obtained RWC of the coriander with pulse irrigation was $90.40 \%$, whereas for continuously-irrigated plants this content was $89.41 \%$, which represents an increase of $1.10 \%$. This increase is because the plant was turgid, since less evaporation of soil water was observed, ensuring the normal maintenance of physiological processes, such as water absorption at the cellular level by the vacuoles, allowing normal plant growth (UPV, 2017).

Evaluating Figure $3 \mathrm{C}$, it is possible to verify that an increase of water depth provided an increase of $0.0004 \%$ in shoot mass production index (SMPI) for each $1 \%$ increase in replacement water depth independently of the type of application. The authors highlight the importance to observe that as SMPI increases, RMPI decreases proportionally, due to higher nutrient and water accumulation in shoot area when comparing to root (Figures 3C, 3E).

Pulse-irrigated plants showed higher values for SMPI $(p>0.01)$ in comparison to continuously-irrigated plants. The authors concluded that plants under pulse irrigation produced $2.27 \%$ more shoot mass than plants under continuous irrigation. Adopting pulse irrigation is notoriously advantageous since it favors higher development to shoot part of plant, considering that this is essential as this is the commercial part of the crop (Figure 3D).

For root mass production index (RMPI), the authors observed as the value of replacement water depth of ETc increased in one unit, RMPI decreased in $0.0004 \%$, independently of the type of application (Figure 3E). This decrease is directly related to plant water content; if water content decreases, a higher concentration of dry matter in the root occur, to the detriment of the shoot area which is the commercial part of the crop.

When plants were pulse irrigated, RMPI observed was 20\% lower than RMPI of plants continuously irrigated (Figure 3F). The highest RMPI in the treatments with continuous irrigation is directly realted to the fact that water deficit stimulates a higher development and root system expansion for deeper and wetter soil layers, causing displacement of a large part of the photoassimilates produced for the greater formation of this organ, to the detriment of other vegetative and reproductive parts of the plant (Santos \& Carlesso, 1998; Albuquerque, 2015). The opposite happens in pulse irrigation, where a constant wet bulb in the root zone is guaranteed by better water availability conditions and lower evaporation and deep percolation losses.

Evaluating effect of drip pulses and soil cover in formation of wet bulb and lettuce productivity, Almeida (2012) observed a greater superficial root proliferation in the first centimeters of the soil; this fact was attributed to the effect of pulse irrigation, considering that as water supply occurs more frequently, it probably favors productivity.

The improvement generated by the pulses on the bulb wetted in root was also verified by Bakeer et al. (2009), studying the effect of pulse irrigation on potato crop, concluded that replacing $100 \%$ of the required humidity, the volume of wet soil is greater in pulse irrigation in $48 \%$ than in the continuous application.

In relation to root-shoot ratio ( $\mathrm{RSr}$ ) a linear reduction of 0.0005 per unit increase of replacement water depth of ETc (Figure 3G) was observed. This decreasing highlights that under water stress, root growth stimulus and shoot growth reduction was observed.

According to Figure $3 \mathrm{H}$, the authors verified that continuously-irrigated plants showed RSr 18.18\% higher than plants submitted to pulse irrigation. This high value of RSr observed in continuous application is due to a relative increase of root surface in comparison to shoot area. This root surface increase is caused by a greater need of water and nutrient absorption in soil, resulting in a decrease of shoot mass, due to greater nutrient translocation to form new root tissue. The opposite was noticed in pulse irrigation: lower RSr indicates a better condition in relation to water and nutrient absorption by the root.

Values of WPFM, WPDM, SWC, RWC and SMPI were superior for pulseirrigated plants, whereas RMPI and $\mathrm{RSr}$ were superior in continuous irrigation. This makes it clear that water deficit was maintained in this type of application. The reduction of the applied irrigation water depths increased plant water stress index. Splitting irrigation used in this experiment ensured enough water content to keep crop quality, besides mitigating the negative effects of water stress conditions, meaning higher SMPI and lower RMPI.

\section{ACKNOWLEDGEMENTS}

The authors thank CAPES (Coordenação de Aperfeiçoamento de Pessoal de Nível Superior) and CNPq (Conselho Nacional de Desenvolvimento Científico e Tecnológico) for financial support for the project.

\section{REFERENCES}

ABDELRAOUF, RE; ABOU-HUSSEIN, SD; REFAIE, KM; EL-METWALLY, IM. 2012. Effect of pulse irrigation on clogging emitters, application efficiency and water productivity of potato crop under organic agriculture conditions. Australian Journal of Basic and Applied Sciences 6: 807-816.

ALBUQUERQUE, AHP. 2015. Distribuição da umidade do solo no cultivo da goiabeira sob altas frequências de irrigação e diferentes coberturas mortas. Ceará: UFC. 87p (Ph.D. thesis).

ALMEIDA, WF. 2012. Gotejamento por pulsos e cobertura do solo na formação do bulbo molhado e produtividade da alface americana. Minas Gerais: UFLA. 80p (Ph.D. thesis).

ALMEIDA, WF; LIMA, LA; PEREIRA, GM. 2015. Drip pulses and soil mulching effect on American crisphead lettuce yield. Engenharia Agrícola 35: 1009-1018.

BAKEER, GAA; EL-EBABI, FG; EL-SAIDI, MT; ABDELGHANY, ARE. 2009. Effect of pulse drip irrigation on yield and water use efficiency of potato crop under organic agriculture in sandy soils. Journal of 
Agricultural Engineering 26: 736-765.

BENINCASA, MMP. 1988. Análise de crescimento de plantas. Noções Básicas. Jaboticabal: FUNEP/FCAV-UNESP. 42p.

CASTRO, CN. 2013. A agricultura no nordeste brasileiro: Oportunidades e limitações ao desenvolvimento. Boletim regional, urbano e ambiental, Instituto de Pesquisa Econômica Aplicada 8: 77-89.

CAVALCANTI, FLA; SANTOS, JCP; PEREIRA, JR.; LEITE, JP; SILVA, MCL; FREIRE, FJ; SILVA, DJ; SOUSA, AR; MESSIAS, AS; FARIA, CMB; BURGOS, N; LIMA JÚNIOR, MA; GOMES, RV; CAVALCANTI, AC; LIMA, JFVF. 2008. Recomendações de adubação para o estado de Pernambuco $\left(2^{a}\right.$ aproximação). Recife: IPA. 212p.

EID, AR; BAKRY, BA; TAHA, MH. 2013. Effect of pulse drip irrigation and mulching systems on yield, quality traits and irrigation water use efficiency of soybean under sandy soil conditions. Agricultural Sciences 4: 249-261.

FERREIRA, DF. 2011. Sisvar: a computer statistical analysis system. Ciência e Agrotecnologia 35: 1039-1042.

FURLANI, PR. 1998. Instruções para o cultivo de hortaliças de folhas pela técnica de Hidroponia NFT. Campinas: Instituto Agronômico. 30p.

IDSO, SB; JACKSON, RD; REGINATO, RJ. 1977. Remote-sensing of crop yields. Science 196: 19-25.

JALES, MC; FEITOSA, FAN; KOENING, ML; BASTOS, RB; MACHADO, RCA. 2012. O ecossistema recifal de Serrambi (nordeste do Brasil): biomassa fitoplanctônica e parâmetros hidrológicos. Atlântica 34: 87-102.

LIMA, AD; NOBRE, JGA; VIANA, TVA; MOREIRA, LG; AZEVEDO, BMA; ALBUQUERQUE, AHP. 2011. Influência de níveis de irrigação, estimados a partir da evaporação medida no evaporímetro de Piche, na cultura da mamoneira. Agropecuária Técnica 32: 42-48.

MACIEL, GM; COSTA, CP; SALA, FC. 2012. Linhagens de coentro com pendoamento tardio sob dois sistemas de plantio. Horticultura Brasileira 30: 607-612.

MAGALHÃES, ACN. 1979. Análise quantitativa do crescimento. In: FERRI, MG (ed). Fisiologia vegetal. São Paulo: USP. p.331-350.

MEDEIROS, JF; MEDEIROS, DS; PORTO FILHO, FQ; NOGUEIRA, ICC. 1998. Efeitos da qualidade e quantidade da água de irrigação sobre o coentro cultivado em substrato inicialmente salino. Revista Brasileira de Engenharia Agrícola e Ambiental 2: 22-26.

MERRIAM, JL; KELLER, J. 1978. Farm irrigation system evaluation: a guide for management. Logan: Utah State University. 271p.

NASCIMENTO, T; AZEVEDO, CAV; NETO, JD; LIMA, VLA; WANDERLEY, JAC. 2013. Velocidade da frente de umidade em neossolo quartzarênico sob irrigação intermitente por gotejamento. Revista Verde de Agroecologia e Desenvolvimento Sustentável 8: 41-48.

SANTOS, RF; CARLESSO, R. 1998. Déficit hídrico e os processos morfológico e fisiológico das plantas. Revista Brasileira de Engenharia Agrícola e Ambiental 2: 287-294.

UPV Univerdidad Politecnica de Valencia. 2017. February 15. La vacuola vegetal y las sustancias ergasticas. Available http://www. euita.upv.es/varios/biologia/temas/La\%20 Vacuola.htm.

WARNER, R; HOFFMAN, O; WILHOIT, J. 2009. The effects of pulsing drip irrigation on tomato yield and quality in Kentucky. Fruit and Vegetable Crop Research Report 1:39-40. 